\title{
Arbuscular Mycorrhizal Fungi (Rhizophagus clarus) and Rhizobacteria (Bacillus subtilis) Can Improve the Clonal Propagation and Development of Teak for Commercial Plantings
}

\section{OPEN ACCESS}

Edited by:

Jan Jansa,

Academy of Sciences of the Czech Republic (ASCR), Czechia

Reviewed by: Jana Rydlová, Institute of Botany (ASCR), Czechia Weria Weisany,

Islamic Azad University, Iran

${ }^{*}$ Correspondence: Martha Viviana Torres Cely vivianatorrescely95@gmail.com

Specialty section

This article was submitted to Plant Symbiotic Interactions,

a section of the journal

Frontiers in Plant Science

Received: 12 November 2020 Accepted: 05 May 2021 Published: 02 July 2021

Citation:

Alexandre FS, Della Flora LV

Henrique IG, da Silva DC, Mercedes AP, Cardoso Silva A, Silva de Oliveira A

Bondespacho da Silva MP, Formelh Ronning BP, Dreher DR, Gionco Cano B, Andreata MFL,

Barbosa Filho J, Santos ER, Takisawa FH, Alfenas RF, Andrade G and Cely MVT (2021) Arbuscular Mycorrhizal Fungi (Rhizophagus clarus) and Rhizobacteria (Bacillus

subtilis) Can Improve the Clonal Propagation and Development of Teak for Commercial Plantings.

Front. Plant Sci. 12:628769. doi: 10.3389/fpls.2021.628769
Flávia Sampaio Alexandre ${ }^{1}$, Larissa Venturini Della Flora ${ }^{1}$, Ivanildo Guilherme Henrique ${ }^{1}$, Daniely Camila da Silva ${ }^{1}$, Andreza Pereira Mercedes ${ }^{1}$, Aline Cardoso Silva ${ }^{1}$, Afonso Silva de Oliveira ${ }^{1}$, Mariane Patrícia Bondespacho da Silva ${ }^{1}$, Bruna Patrícia Formelh Ronning ${ }^{1}$, Douglas Rafael Dreher ${ }^{1}$, Bárbara Gionco Cano ${ }^{2}$, Matheus Felipe de Lima Andreata ${ }^{2}$, Joamir Barbosa Filho ${ }^{3}$, Eva Roseane Santos ${ }^{3}$, Fausto Hissashi Takisawa ${ }^{3}$, Rafael Ferreira Alfenas ${ }^{4}$, Galdino Andrade ${ }^{2}$ and Martha Viviana Torres Cely ${ }^{1 *}$

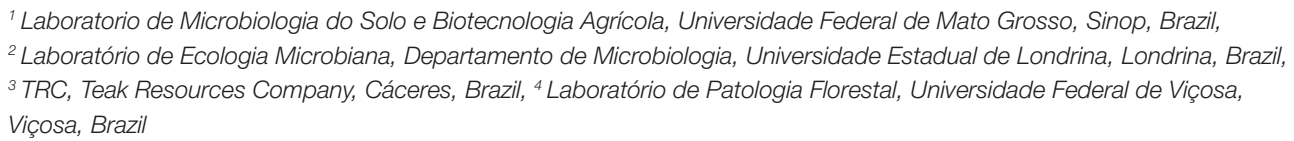

The Tectona grandis L.f. (teak) is an important forest species with high economy value in Asia, Africa, and Latin America. In Latin America, Brazil is one of the countries with the most cultivated areas. The cultivation of teak turns out to be challenging because of its high nutritional demand and the need for seedling production by clonal propagation that includes about 90 days in the nursery phase. The optimization of seedling production is necessary for better results in the nursery and to enhance growth in the field. In this way, the well-known advantage of using microorganisms that promote plant development appears as a potential biotechnological approach to be explored and for the implantation of new areas of wood production. In this study, the inoculation of Bacillus subtilis as plant growth-promoting rhizobacteria (PGPR) was evaluated, and Rhizophagus clarus, an arbuscular mycorrhizal fungus (AMF), and the co-inoculation of these microorganisms in the teak seedling production phase can improve the development of commercial plantations under field conditions. Experiments were carried out under greenhouse and field conditions to evaluate four treatments based on the substrate inoculation of the seedlings. Treatments consisted of a non-inoculated control, PGPR inoculation, AMF inoculation, and PGPR + AMF inoculation. The results of the biometric evaluation of seedlings in the greenhouse showed that there was a significant difference in AMF inoculation and PGPR + AMF inoculation in terms of the specific root length and root density treatments, there was also a positive correlation between these two treatments and the absorption of some nutrients, such as $\mathrm{P}, \mathrm{N}, \mathrm{K}, \mathrm{Mg}, \mathrm{Cu}, \mathrm{Mn}$, and $\mathrm{Zn}$. This response led to an increase between 4.75 and $11.04 \%$ in the field growth rate.

Keywords: forestry, nursery, soil microbiology, Tectona grandis, wood production 


\section{INTRODUCTION}

The forestry sector has become increasingly important for the Brazilian gross domestic product (GDP), having 1.3\% share in 2018, reaching a total revenue of 86.6 billion. The cultivation of trees for industrial purposes is a renewable source of raw material for almost 5,000 products, such as sawn wood, paper, cellulose, floors, panels, and charcoal, being an important weapon in the recovery of degraded areas and protection of habitats (IBÁ, 2019).

Being one of the main nobles manufactured in the world, teak (Tectona grandis L.f.) is a tree species in the Lamiaceae family, native to the Asian continent, initiated throughout tropical Asia, as well as tropical Africa, Latin America, and the Caribbean. It is characterized by its soft color, fine grain, and durability, and it is commonly used for products of high commercial value, such as furniture, shipbuilding, and decorative construction components (Pandey and Brown, 2000). In Brazil, 93,957 ha of planted areas of this species were registered in 2018 (IBÁ, 2019).

A limiting factor for its cultivation is the low germination rate of seeds and their sensitivity to storage, with genetic improvement being one of the main alternatives to this problem, bringing long-term results (Schuhli and Paludzyszyn Filho, 2010). In this scenario, the clonal production of selected trees has been boosted. The mini-cutting technique can provide, in the short term, homogeneous seedlings with desired characteristics, increase the number of rooted mini-cuttings, and improve the root system, directly influencing the performance of seedlings in the field (Meza et al., 2015).

The inoculation of plant growth-promoting rhizobacteria (PGPR) during seedling production has already proved efficient, generating healthier plants with gains in biomass and nutrient content (Rodrigues et al., 2018; Raghu et al., 2020). Moreover, the response of teak to different and selected microbial consortiums, such as Ambispora leptoticha, Azotobacter chroococcum, and Trichoderma harzianum has already been tested (Raghu et al., 2020). Among the PGPR, Bacillus is one of the most important genera in soil, and its ability to generate spores increases its survival and competitiveness in adverse conditions. The genus assists plants in their defense against attacks by pathogens and increases their tolerance to stress (Hashem et al., 2016).

Arbuscular mycorrhizal fungi (AMF) also improve plant growth (Akinrinlola et al., 2018). AMF are able to promote growth, and they are resistant to biotic and abiotic stresses, because of greater absorption of nutrients, with emphasis on phosphorus (P) (Smith and Read, 2008). They increase the formation of soil aggregates through the production of glomalin, and they are also important regulators of soil stability and quality (Rillig and Mummey, 2006). A greenhouse study demonstrated the beneficial effect of AMF inoculation on teak seedlings, with greater growth of aerial parts and roots, content of nutrients, such as potassium (K) and sulfur (S), and better efficiency in the use of nutrients, such as P (Rodrigues et al., 2018). Another study conducted to examine the efficacy of three native species of AMF (Funneliformis mosseae, Glomus intradices, and Glomus proliferum) on the growth and seedling quality of $T$ grandis showed that mycorrhizal symbiosis significantly improved seedling growth and physiological parameters, proving that this technology has a potential to reduce the nursery period and that it increases the quality of produced seedlings, resulting in considerable economic gains (Ajeesh et al., 2017).

The inoculation of AMF and Bacillus species and the coinoculation of these microorganisms have already been proven as efficient methods to increase plant growth by several researchers (Medina et al., 2003; Marulanda-Aguirre et al., 2007; Alam et al., 2011; Awasthi et al., 2011). B subtilis is sold commercially (Biobaci ${ }^{\circledR}$ ), and $R$ clarus is in the process of launching the commercial product (Andrade and Cely, 2019), facilitating the implantation of these microorganisms in the operational routine of companies for the production of teak seedlings. Thus, this study aims to demonstrate the effect of AMF R clarus and PGPR $B$ subtilis, their co-inoculation interaction in the nursery phase, and their potential to improve the growth process of $T$ grandis under field conditions.

\section{MATERIALS AND METHODS}

\section{Seedling Experiments}

The experiment was carried out in the Teak Resources Company (TRC) seedling nursery, located in Jangada city, MT, Brazil from September 2016 to January 2017. The principal commercial clone of the company was multiplied by mini-cutting systems from clonal garden. Microorganisms were incorporated in the substrate of pine bark (Mec Plant - Florestal 2) fertilized with Osmocote Mini Prill-3M ( $\mathrm{N} \mathrm{19 \% ,} \mathrm{P}_{2} \mathrm{O}_{5} 6 \%$, and $\mathrm{K}_{2} \mathrm{O} 10 \%$ ) $-8 \mathrm{~g}+\mathrm{PG}$ Mix (N 14\%, $\mathrm{P}_{2} \mathrm{O}_{5} 16 \%$, and $\mathrm{K}_{2} \mathrm{O} 18 \%$ ) $-5 \mathrm{~g} / \mathrm{kg}$ of substrate. Before planting, mini-cuttings were dipped in indole butyric acid (IBA) $\left(500 \mathrm{mg} \mathrm{L}^{-1}\right)$ and then planted in tubes of 53 $\mathrm{cm}^{3}$. The treatments presented in Table $\mathbf{1}$ are considered. Two types of microorganisms were inoculated: AMF $R$ clarus, with a concentration of 200 propagules $/ \mathrm{ml}$ multiplied in vitro system according to the patent application: BR 102019008109-0 A2 of 22/04/2019 (Andrade and Cely, 2019) and commercial product Biobaci ${ }^{\circledR}$ containing viable cells $\left(1 \times 10^{8} \mathrm{CFU} / \mathrm{ml}\right)$ of PGPR $B$ subtilis. In total, 2,112 seedlings were produced (528 seedlings per treatment). A completely randomized design was chosen under greenhouse conditions.

The mini-cuttings were kept in an air-conditioned greenhouse with a transparent polyethylene cover and $50 \%$ shadowing fabric for 30 days. Parameters, namely, relative humidity $(\mathrm{RH}>$ $80 \%)$, temperature $\left(35-40^{\circ} \mathrm{C}\right)$, and irrigation were controlled via nebulization. In the 1st week, the frequency of irrigation was $10 \mathrm{~s}$

TABLE 1 | Treatments and doses used for incorporation into the substrate of microorganisms Rhizophagus clarus and Bacillus subtilis in the production of Tectona grandis seedlings.

\begin{tabular}{ll}
\hline Treatment & Description \\
\hline $\mathrm{T} 1$ & Control (substrate without microorganisms) \\
$\mathrm{T} 2$ & PGPR (Bacillus subtilis) $-50 \mathrm{~mL} / \mathrm{L}$ of substrate \\
$\mathrm{T} 3$ & AMF (Rhizophagus clarus) $-15 \mathrm{~g} / \mathrm{L}$ of substrate \\
$\mathrm{T} 4$ & PGPR + AMF(Bacillus subtilis $-50 \mathrm{~mL}+$ \\
& Rhizophagus clarus $-15 \mathrm{~g} / \mathrm{L}$ of substrate)
\end{tabular}


each $15 \mathrm{~min}$; and in the following weeks, the frequency was $20 \mathrm{~s}$ each $40 \mathrm{~min}$ ( $24 \mathrm{~L} / \mathrm{h} /$ micro sprinkler). Subsequently, they were placed in the shade house with $50 \%$ shadowing fabric and $4 \mathrm{~h}$ of irrigation for $15 \mathrm{~min}$, for acclimatization until they reached
60 days. During this phase, the seedlings were fertigated once a day with $600 \mathrm{mg}$. $\mathrm{L}^{-1}$ of the following substances: $\mathrm{MgSO}_{4} 7 \mathrm{H}_{2} \mathrm{O}$, $\mathrm{Ca}\left(\mathrm{NO}_{3}\right)_{2}$, and $\mathrm{NH}_{4} \mathrm{NO}_{3}$ each; $800 \mathrm{mg}$. $\mathrm{L}^{-1}$ of $\mathrm{NH}_{4} \mathrm{H}_{2} \mathrm{PO}_{4}$, and $400 \mathrm{mg} . \mathrm{L}^{-1}$ of $\mathrm{KNO}_{3}$. After this period, the seedlings went full

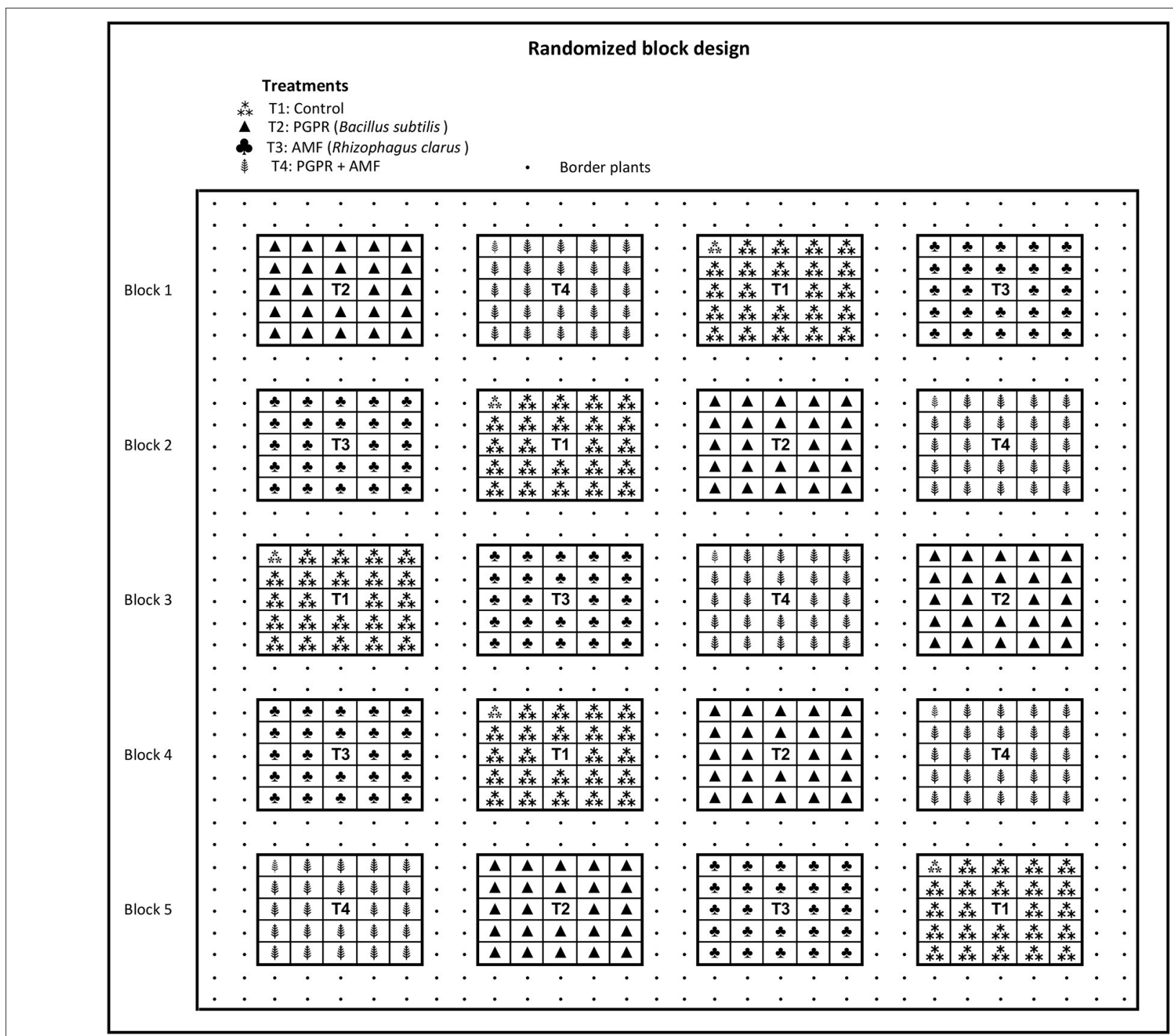

FIGURE 1 | Randomized block design of field experiments with Tectona grandis in states Mato Grosso and Pará, Brazil.

TABLE 2 | Summary of the general linear models (GLMs) of Tectona grandis seedling survival at 30, 60, and 90 days in nursery.

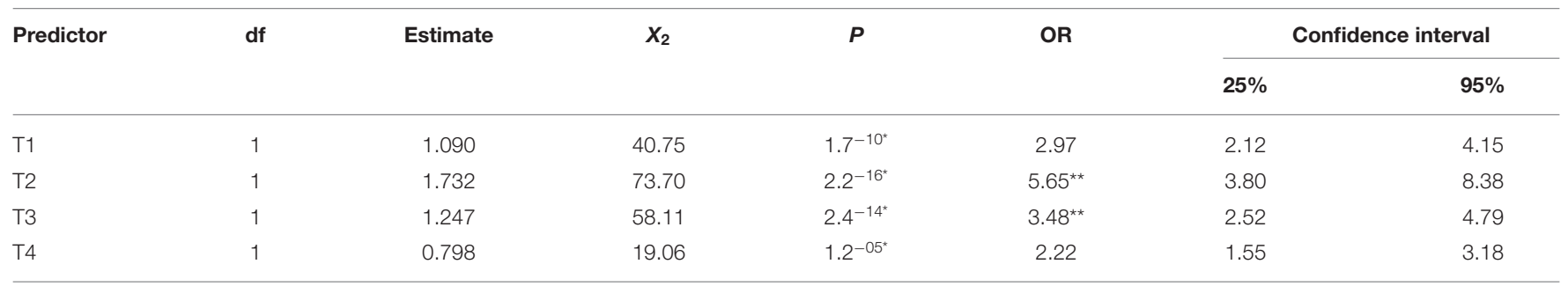

${ }^{*}$ Significant predictors at $(p \leq 0.001)$.

**Highest odds ratio for survival. 
sun until they completed 90 days. The frequency of irrigation was every $6 \mathrm{~h}$ for $10 \mathrm{~min}(810 \mathrm{~L} / \mathrm{h} / \mathrm{micro}$ sprinkler $)$, and fertigation was performed twice a week with the same nutrient solution mentioned above.

\section{Data Collected in Nursery Phase}

Seedling survival was evaluated 30,60 , and 90 days after planting. Ninety days after planting, 20 seedlings per treatment were collected for biometric analysis in the laboratory. At this time, height $=\mathrm{H}(\mathrm{cm})$, stem diameter $=\mathrm{SD}(\mathrm{mm})$, dry shoot biomass $=\mathrm{SB}(\mathrm{g})$, root biomass $=\mathrm{RB}(\mathrm{g})$ and biomass ratio of the root/shoot $=\mathrm{RB} / \mathrm{SB}(\mathrm{g})$ were evaluated. The remaining seedlings were intended for field experiments.

Ten root seedlings samples per treatment were also collected to evaluate mycorrhizal colonization. The percentage of mycorrhizal colonization was estimated by the grid-line method (Giovannetti and Mosse, 1980) after staining roots with Trypan blue (0.05\%) (Phillips and Hayman, 1970). Total root length = TRL $(\mathrm{cm})$, specific root length $=\mathrm{SRL}\left(\mathrm{cm} \mathrm{g}^{-1}\right)$, and root density $=\mathrm{RD}\left(\mathrm{g} \mathrm{cm}^{-3}\right)$ were also evaluated at this stage (Ryser and Lambers, 1995). Twenty seedling samples per treatment were separated for macro and micronutrient foliar analysis; and for this, the following methods were used sulfuric digestion and quantification by titration after semi-micro Kjeldahl distillation $(\mathrm{N})$, nitric-perchloric digestion ( $\mathrm{P}, \mathrm{K}, \mathrm{Ca}, \mathrm{Mg}, \mathrm{S}, \mathrm{Cu}, \mathrm{Fe}, \mathrm{Mn}$, $\mathrm{Zn}, \mathrm{Na}$, and $\mathrm{Ni}$ ), incineration (B, Co, and $\mathrm{Mo})$, agitation $(\mathrm{Cl})$. Sample reading was made by inductively coupled plasma-optical emission spectrometry (ICP-OES) with a Thermo Scientific ICAP 7600 spectrometer (Thermo Fisher Scientific, Waltham, Massachusetts, US).

\section{Field Experiments}

The field experiments were started in February 2017. Two experimental areas were used. Area I is located in Cáceres city, state of Mato Grosso (MT), Brazil ( $16^{\circ} 8^{\prime} 1.75^{\prime \prime} \mathrm{S}$ and $58^{\circ} 31^{\prime} 1.77^{\prime \prime}$ $\mathrm{W})$ and has tropical savanna climate (Aw) (Köppen, 1936) and soil classification We-Eutric Planosols (FAO, 1994). Area II is located in Santa Maria das Barreiras city, state of Pará (PA), Brazil $\left(8^{\circ} 43^{\prime} 1.11^{\prime \prime} \mathrm{S}\right.$ and $\left.50^{\circ} 29^{\prime} 10.76^{\prime \prime} \mathrm{W}\right)$ and has tropical savanna climate (Aw) (Köppen, 1936) and soil classification Ao-Orthic Acrisols (FAO, 1994). Soil samples were collected in Area I and Area II for physicochemical analysis at depths of 0-20 and 20$40 \mathrm{~cm}$. The analysis showed the following results: Area I depth 0-20 cm: $\mathrm{pH}\left(\mathrm{CaCl}_{2}\right) 5.1, \mathrm{Al}^{+3} 0 \mathrm{cmol}_{\mathrm{c}} \mathrm{dm}^{-3}, \mathrm{H}+\mathrm{Al} 2.48 \mathrm{cmol}_{\mathrm{c}}$ $\mathrm{dm}^{-3}, \mathrm{P} 3.5 \mathrm{mg} \mathrm{dm}^{-3}, \mathrm{~K}^{+} 30.3 \mathrm{mg} \mathrm{dm}^{-3} ; \mathrm{Ca}^{+2} 1.5 \mathrm{cmol}_{\mathrm{c}} \mathrm{dm}^{-3}$, and $\mathrm{Mg}^{+2} 0.58 \mathrm{cmol}_{\mathrm{c}} \mathrm{dm}^{-3}$. Depth $20-40 \mathrm{~cm}$ with $\mathrm{pH}\left(\mathrm{CaCl}_{2}\right)$ 4.6, $\mathrm{Al}^{+3} 0.28 \mathrm{cmol}_{\mathrm{c}} \mathrm{dm}^{-3}, \mathrm{H}+\mathrm{Al} 2.25 \mathrm{cmol}_{\mathrm{c}} \mathrm{dm}^{-3}, \mathrm{P} .3 \mathrm{mg}$ $\mathrm{dm}^{-3}, \mathrm{~K}^{+} 16.2 \mathrm{mg} \mathrm{dm}{ }^{-3} ; \mathrm{Ca}^{+2} 0.90 \mathrm{cmol}_{\mathrm{c}} \mathrm{dm}^{-3}$, and $\mathrm{Mg}^{+2}$ $0.37 \mathrm{cmol}_{\mathrm{c}} \mathrm{dm}^{-3}$. Area II depth 0-20 cm: $\mathrm{pH}\left(\mathrm{CaCl}_{2}\right) 4.5, \mathrm{Al}^{+3}$ $0.2 \mathrm{cmol}_{\mathrm{c}} \mathrm{dm}^{-3}, \mathrm{H}+\mathrm{Al} 2.2 \mathrm{cmol}_{\mathrm{c}} \mathrm{dm}^{-3}, \mathrm{P} 1.8 \mathrm{mg} \mathrm{dm}^{-3}, \mathrm{~K}^{+}$ $24.6 \mathrm{mg} \mathrm{dm}^{-3}, \mathrm{Ca}^{+2} 1.2 \mathrm{cmol}_{\mathrm{c}} \mathrm{dm}^{-3}$, and $\mathrm{Mg}^{+2} 0.4 \mathrm{cmol}_{\mathrm{C}} \mathrm{dm}^{-3}$. Depth $20-40 \mathrm{~cm}$ with $\mathrm{pH}\left(\mathrm{CaCl}_{2}\right) 4.4, \mathrm{Al}^{+3} 0.2 \mathrm{cmol}_{\mathrm{c}} \mathrm{dm}^{-3}$, P. $5 \mathrm{mg} \mathrm{dm}^{-3}, \mathrm{~K}^{+} 19.5 \mathrm{mg} \mathrm{dm}^{-3}, \mathrm{Ca}^{+2} 0.80 \mathrm{cmol}_{\mathrm{c}} \mathrm{dm}^{-3}$; and $\mathrm{Mg}^{+2} 0.3 \mathrm{cmol}_{\mathrm{c}} \mathrm{dm}^{-3} \cdot \mathrm{pH}\left(\mathrm{CaCl}_{2}\right)$ was evaluated in a $0.01 \mathrm{M}$ chloride solution, in the proportion 1:2.5 (soil: $\mathrm{CaCl}_{2}$ ). $\mathrm{P}$ and $\mathrm{K}^{+}$ were extracted with a $0.05 \mathrm{~N} \mathrm{HCl}$ and $0.025 \mathrm{~N} \mathrm{H}_{2} \mathrm{SO}_{4}$ solution
(Mehlich I). $\mathrm{Ca}^{+2}, \mathrm{Mg}^{+2}$, and $\mathrm{Al}^{+3}$ were extracted with a $1 \mathrm{~N}$ potassium chloride solution.

These experiments were carried out in a randomized block design. Five blocks were installed, and within each block four plots of $5 \times 5$ plants ( 25 plants per plot) were used. Each plot corresponds to one of the treatments defined in the nursery phase (Table 1), separated by two border plants (Figure 1). Plant spacing was $3 \times 4 \mathrm{~m}$. Total experimental area was 1.33 ha of planting including border plants. For the implantation and conduction of planting, the standard routine of the company was followed.

\section{Data Collected in Field}

Plant survival was evaluated 30,60, and 90 days after planting in the field. Data collection was made 2 and 3 years after planting. The data collected in this time were: height $=\mathrm{H}(\mathrm{m})$ and diameter at breast height $=\mathrm{DBH}(\mathrm{cm})$, tree volumes $=\mathrm{V}\left(\mathrm{dm}^{3}\right)$ and were calculated with these data, using the equation $\left[\pi *\left(\mathrm{DBH}^{2} / 4\right) *\right.$ $\mathrm{H} * \mathrm{Ff}]$. The artificial form factor $=\mathrm{Ff}=0.63$ was used, the average value indicated for young teak plantation, between 1 and 3 years old (Carneiro et al., 2018). Additionally, the mean annual increment $=$ MAI $\left(\mathrm{dm}^{3}\right.$ year $\left.{ }^{-1}\right)$ and the current annual increment $=\mathrm{CAI}(\mathrm{dm} 3)$ were estimated.

TABLE 3 | Percentage of mycorrhizal colonization of Tectona grandis seedling at 90 days.

\begin{tabular}{lc}
\hline Treatment & Mycorrhizal colonization (\%) \\
\hline T1 - Control & $0.0^{\mathrm{b}}$ \\
T2 - PGPR & $0.0^{\mathrm{b}}$ \\
T3 - AMF & $63.4^{\mathrm{a}}$ \\
T4 - PGPR+ AMF & $61.8^{\mathrm{a}}$ \\
\hline
\end{tabular}

Treatments with the same letter are not significantly different by Friedman test $(p \leq 0.05)$.

TABLE 4 | Analysis of variance (ANOVA) for treatments of seedling growth parameters of Tectona grandis at 90 days after mini-cuttings planting.

\begin{tabular}{llccc}
\hline Variables & df & $\boldsymbol{F}$ & $\boldsymbol{p}$-value & Error \\
\hline ANOVA & & & & \\
$\mathrm{H}$ & 3 & 0.834 & 0.48000 & 31.30 \\
$\mathrm{SD}$ & 3 & 5.588 & $0.00162^{*}$ & 0.951 \\
$\mathrm{SB}$ & 3 & 2.333 & 0.08070 & 0.870 \\
$\mathrm{RB}$ & 3 & 3.345 & $0.02350^{*}$ & 0.228 \\
$\mathrm{RB} / \mathrm{SB}$ & 3 & 1.974 & 0.13500 & 0.096 \\
$\mathrm{TRL}$ & 3 & 0.670 & 0.57600 & 369.2 \\
$\mathrm{SRL}$ & 3 & 3.631 & $0.02190^{*}$ & 0.002 \\
$\mathrm{RD}$ & 3 & 4.520 & $0.00864^{*}$ & 0.013 \\
& & & &
\end{tabular}

$H(\mathrm{~cm})$, Height; $S D(\mathrm{~mm})$, stem diameter; $S B(\mathrm{~g})$, dry shoot biomass; $R B(\mathrm{~g})$, root biomass; $R B / S B(g)$, biomass ratio of the root/shoot; TRL $(\mathrm{cm})$, total root length; $S R L\left(\mathrm{~cm} \mathrm{~g}^{-1}\right)$, specific root length; $R D\left(\mathrm{~g} \mathrm{~cm}^{-3}\right)$, root density.

*Significant difference $(p \leq 0.05)$. 


\section{Statistical Analysis}

To evaluate the effects of treatments on seedling survival, we performed generalized linear models (GLMs) analysis. For models, the treatments (T1, T2, T3, and T4) were used as predictors and the time as an independent factor. The statistical significance $(\mathrm{p})$ of each predictor is based on chi-square tests to assess the significance of the change in deviance for each predictor. For model interpretation, the odds ratio (OR) and its confidence interval were calculated.

Statistical analyses of AMF root colonization were performed using the Friedman test at a significance level of $p \leq 0.05$. Plant growth parameters in the seedling experiments were analyzed by analysis of variance (ANOVA) and the Tukey test $(p \leq 0.05)$. Principal component analysis (PCA) was also performed for nutrient content. Analyses of field data at 2 and 3 years after planting were performed by factorial ANOVA. Factor A: treatment. Factor B: block. For comparison of means, the Tukey test $(p \leq 0.05)$ was performed. All statistical analyses in this research were performed using the $\mathrm{R}$ software (R Core Team, 2020).

\section{RESULTS}

\section{Seedling Test}

The results of GLMs based on the patterns of seedling survival in the nursery phase revealed significant effects of treatments as
A

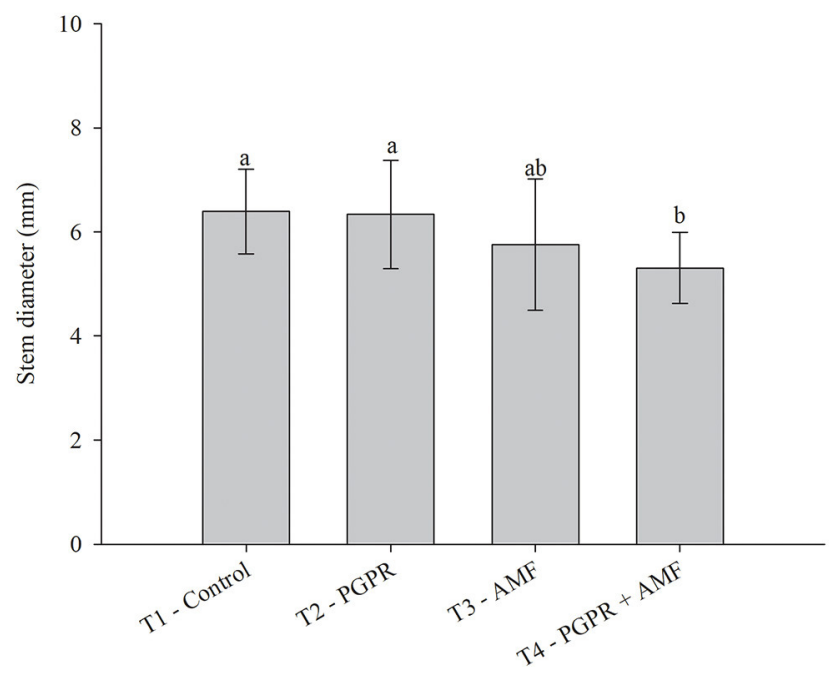

C



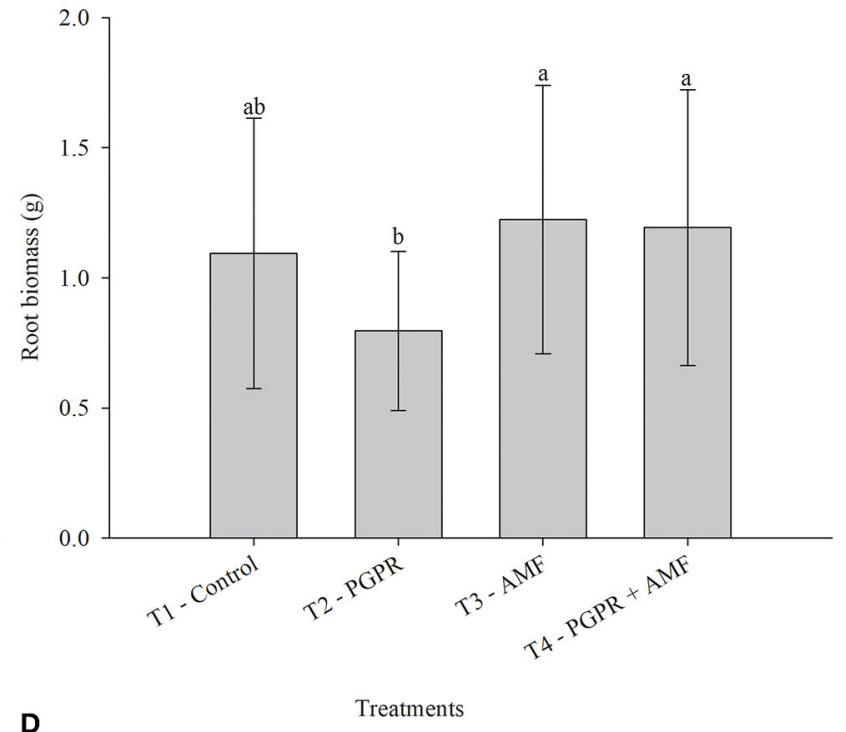

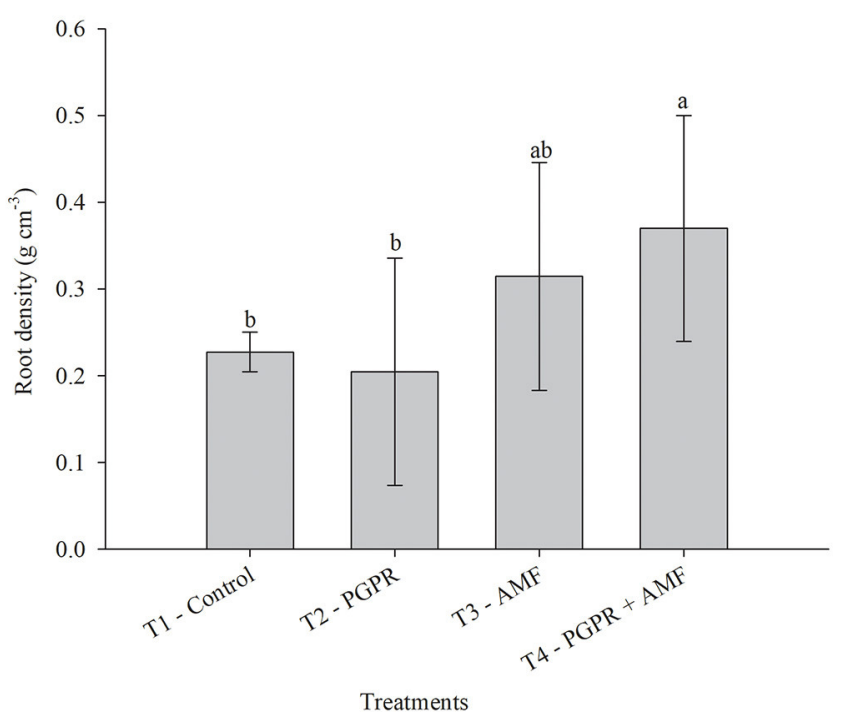

FIGURE 2 | Effect on seedling growth of Tectona grandis at 90 days. (A) Stem diameter. (B) Root biomass. (C) Specific root length. (D) Root density $(n=20)$. Bars followed by the same letter do not differ by Turkey test $(p \leq 0.05)$. Bars represent standard deviation of means. 


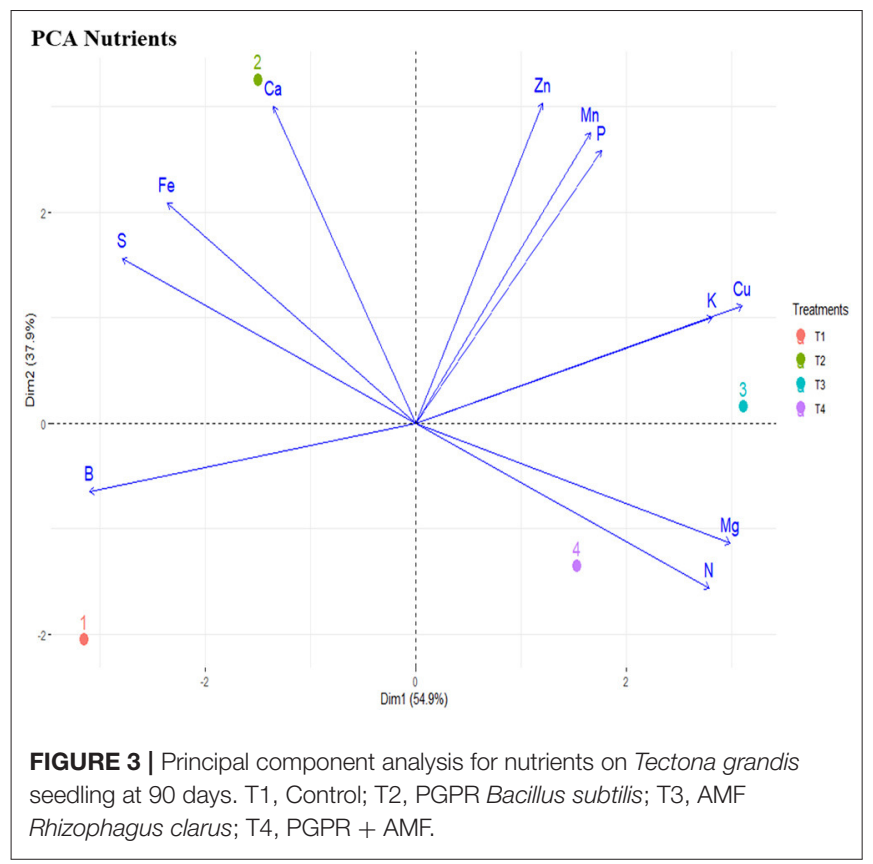

predictors for this parameter. That is, the treatments can be used to explain the survival pattern in this experiment, being that all models were statistically significant $(p<0.001)$. The OR showed better survival for seedlings of teak when inoculated with PGPR (B subtilis) and AMF ( $R$ clarus) (Table 2).

The mycorrhizal colonization in the treatments inoculated with $R$ clarus (AMF) was just over $60 \%$. In general, bacterial inoculation with PGPR did not influence the rate of colonization of teak roots by mycorrhiza (Table 3 ).

In the seedling growth evaluation, the treatments have a significant effect on stem diameter, root biomass, specific root length, and root density ( $p \leq 0.05$ ) (Table 4 ). For stem diameter, the treatments with microorganisms PGPR and AMF were statistically equal to the control, only PGPR + AMF was lower than the control treatment (Figure 2A). AMF inoculation resulted in a significant decrease in root biomass, while the other two microbial treatments did not affect this variable (Figure 2B). The low development of stem diameter in PGPR + AMF was compensated by differentiate response in root system inoculation that showed gains in specific root length and root density (Figures 2C,D).

In the PCA, $92.8 \%$ of the variability of nutrients data were represented in components one and two. In the first dimension, representing $54.9 \%$ of the data variability, macronutrients nitrogen $(\mathrm{N})$, phosphorus $(\mathrm{P})$, and potassium $(\mathrm{K})$ were positively related with treatments T3 and T4 (AMF inoculation and PGPR + AMF inoculation), as well as micronutrients magnesium (Mg), copper $(\mathrm{Cu})$, manganese $(\mathrm{Mn})$, and Zinc $(\mathrm{Zn})$. In the second dimension, representing $37.9 \%$ of the data variability, calcium $(\mathrm{Ca})$, iron $(\mathrm{Fe})$, and sulfur $(\mathrm{S})$ data were associated with treatment T2 (PGPR). The control treatment was allocated far from the eigenvalues of the nutrients, showing that the treatment did not interact with the nutritional data (Figure 3).
TABLE 5 | Summary of the general linear models (GLMs) of Tectona grandis seedling survival at 30,60 , and 90 days in field.

\begin{tabular}{lcccc}
\hline Predictor & df & Estimate & $\boldsymbol{X}_{\mathbf{2}}$ & $\boldsymbol{p}$ \\
\hline Mato Grosso & & & & \\
T1 & 1 & 1.398 & 1.29 & 0.2555 \\
T2 & 1 & 14.27 & $7 e-04$ & 0.9787 \\
T3 & 1 & 14.27 & $7 e-04$ & 0.9787 \\
T4 & 1 & 14.27 & $7 e-04$ & 0.9787 \\
Pará & & & & \\
T1 & 1 & 16.31 & $8^{-04}$ & 0.9781 \\
T2 & 1 & 2.53 & 5.42 & $0.0198^{*}$ \\
T3 & 1 & 16.29 & $5^{-04}$ & 0.9821 \\
T4 & 1 & 16.31 & $8^{-04}$ & 0.9781 \\
\hline
\end{tabular}

*Significant predictors at $(p \leq 0.05)$.

\section{Field Test}

In the field, seedling survival is not explained by the treatments as predictors in GLM in the Mato Grosso area. On the other hand, in Pará, treatment with B subtilis (T2) showed 96\% of seedling survival and was considered a predictor for this parameter with GLM statistically significant $(p<0.05)$. This treatment showed an OR of 12.55 (confidence interval of 2.5-95\%/1.49-105.45) (Table 5).

The tree volume (V) and mean annual increment (MAI) at 2 years after planting in Mato Grosso showed statistical differences between treatments, block, and the interaction between treatment $\times$ block. Treatments T1, T2, and T4 were significantly equal, and treatment $\mathrm{T} 3$ was statistically lower in both variables analyzed. The plants in block 2 performed better than the plants in blocks 3 and 4 . The interaction of the treatment and blocking factors was significant but did not show any clear pattern (Table 6).

At 3 years after planting in Mato Grosso, statistical differences between treatments, block, and the interaction between treatment $\times$ block for $\mathrm{V}$, MAI, and CAI were observed. The results were similar to those presented at 2 years for $\mathrm{V}$ and MAI and for CAI (Table 7).

In Pará, the V and MAI showed statistical differences between treatments, block, and the interaction between treatment $\times$ block at 2 years. The T2 andT4 treatments presented the best results and were statistically superior to T1 and T3. The plants in blocks 1,2 , and 3 performed better than the plants in blocks 4 and 5. The interaction of the treatment and blocking factors was significant but did not show any clear pattern (Table 8).

At 3 years, the V, MAI, and CAI also presented statistical differences between treatments, block, and the interaction between treatment $\times$ block. The best treatment was T2, which differed significantly from the control. In the average value of treatments, PGPR (T2) showed an $11.04 \%$ increase in V at 3 years followed by PGPR + AMF (T4) with 5.81\%, and AMF (T3) with $4.75 \%$ compared with the control. Blocks 1, 2, and 3 presented the best results. The interaction of the treatment and blocking factors was significant but did not show any clear pattern. This difference between the blocks may be due to variations in soil conditions, which is due to the large experimental area (Table 9). 
TABLE 6 | Tree volume and mean annual increment at 2 years old in plants of Tectona grandis in Mato Grosso state, Brazil.

\begin{tabular}{|c|c|c|c|c|c|c|}
\hline \multirow[t]{2}{*}{ Factor } & \multirow[b]{2}{*}{ df } & \multicolumn{2}{|c|}{$V\left(d^{3}\right)$} & \multicolumn{2}{|c|}{ MAI $\left(\mathrm{dm}^{3}\right.$ year $\left.^{-1}\right)$} & \\
\hline & & $\boldsymbol{F}$ & $p$-value & $\boldsymbol{F}$ & $p$-value & \\
\hline \multicolumn{7}{|c|}{ ANOVA - Mato Grosso, 2 years old } \\
\hline Treatment (A) & 3 & 11.37 & $0.0000^{\star}$ & 11.351 & $0.0000^{\star}$ & \\
\hline Block (B) & 4 & 6.13 & $0.0000^{\star}$ & 6.131 & $0.0000^{*}$ & \\
\hline$A \times B$ & 12 & 15.09 & $0.0000^{*}$ & 15.074 & $0.0000^{*}$ & \\
\hline Error & & 0.224 & & 0.056 & & \\
\hline Treatment & & & $V\left(\mathrm{dm}^{3}\right)$ & & & MAI $\left(\mathrm{dm}^{3}\right.$ year $\left.^{-1}\right)$ \\
\hline \multicolumn{7}{|c|}{ Tukey test of treatment } \\
\hline T1 - Control & & & $0.96 \pm 0.46^{a}$ & & & $0.48 \pm 0.23^{a}$ \\
\hline T2 - PGPR & & & $0.92 \pm 0.55^{a}$ & & & $0.46 \pm 0.27^{a}$ \\
\hline T3 - AMF & & & $0.70 \pm 0.33^{b}$ & & & $0.35 \pm 0.16^{b}$ \\
\hline $\mathrm{T} 4$ - PGPR + AMF & & & $1.04 \pm 0.79^{a}$ & & & $0.52 \pm 0.40^{a}$ \\
\hline Block & & & $V\left(d^{3}\right)$ & & & MAI $\left(\mathrm{dm}^{3}\right.$ year $\left.^{-1}\right)$ \\
\hline \multicolumn{7}{|l|}{ Tukey test of block } \\
\hline 1 & & & $0.98 \pm 0.91^{\mathrm{ab}}$ & & & $0.49 \pm 0.45^{a b}$ \\
\hline 2 & & & $1.06 \pm 0.58^{a}$ & & & $0.53 \pm 0.29^{a}$ \\
\hline 3 & & & $0.82 \pm 0.35^{b c}$ & & & $0.41 \pm 0.18^{b c}$ \\
\hline 4 & & & $0.77 \pm 0.35^{c}$ & & & $0.38 \pm 0.17^{\mathrm{c}}$ \\
\hline 5 & & & $0.89 \pm 0.42^{a b c}$ & & & $0.45 \pm 0.21^{a b c}$ \\
\hline Block & T1 - Control & & T2 - PGPR & T3 - AMF & & T4 - PGPR + AMF \\
\hline \multicolumn{7}{|c|}{ Tukey test of $A \times B V\left(\mathrm{dm}^{3}\right)$} \\
\hline 1 & $0.86 \pm 0.44^{\mathrm{cd}}$ & & $0.56 \pm 0.24^{d}$ & $0.55 \pm 0.23^{d}$ & & $1.99 \pm 1.30^{a}$ \\
\hline 2 & $1.16 \pm 0.49^{b c}$ & & $1.53 \pm 0.73^{a b}$ & $0.70 \pm 0.29^{c d}$ & & $0.85 \pm 0.31^{\mathrm{cd}}$ \\
\hline 3 & $0.73 \pm 0.36^{\mathrm{cd}}$ & & $0.89 \pm 0.35^{\mathrm{cd}}$ & $0.81 \pm 0.32^{\mathrm{cd}}$ & & $0.85 \pm 0.37^{c d}$ \\
\hline 4 & $0.92 \pm 0.42^{\mathrm{cd}}$ & & $0.80 \pm 0.30^{\mathrm{cd}}$ & $0.57 \pm 0.25^{d}$ & & $0.81 \pm 0.33^{\mathrm{cd}}$ \\
\hline 5 & $1.13 \pm 0.48^{b c}$ & & $0.80 \pm 0.42^{\mathrm{cd}}$ & $0.90 \pm 0.40^{\mathrm{cd}}$ & & $0.73 \pm 0.24^{\mathrm{cd}}$ \\
\hline \multicolumn{7}{|l|}{ MAI $\left(\mathrm{dm}^{3}\right.$ year $\left.^{-1}\right)$} \\
\hline 1 & $0.43 \pm 0.22^{\mathrm{cd}}$ & & $0.28 \pm 0.12^{d}$ & $0.28 \pm 0.12^{d}$ & & $0.99 \pm 0.65^{a}$ \\
\hline 2 & $0.58 \pm 0.25^{b c}$ & & $0.77 \pm 0.37^{a b}$ & $0.35 \pm 0.15^{\mathrm{cd}}$ & & $0.42 \pm 0.16^{\mathrm{cd}}$ \\
\hline 3 & $0.36 \pm 0.18^{\mathrm{cd}}$ & & $0.44 \pm 0.18^{\mathrm{cd}}$ & $0.41 \pm 0.16^{\mathrm{cd}}$ & & $0.42 \pm 0.19^{c d}$ \\
\hline 4 & $0.48 \pm 0.21^{\mathrm{cd}}$ & & $0.40 \pm 0.15^{\mathrm{cd}}$ & $0.28 \pm 0.13^{d}$ & & $0.40 \pm 0.16^{\mathrm{cd}}$ \\
\hline 5 & $0.57 \pm 0.24^{\mathrm{bc}}$ & & $0.40 \pm 0.21^{\mathrm{cd}}$ & $0.45 \pm 0.20^{\mathrm{cd}}$ & & $0.36 \pm 0.12^{\mathrm{cd}}$ \\
\hline
\end{tabular}

${ }^{*}$ Significant difference $(p \leq 0.05)$. Same letter does not differ by the Tukey test $(p \leq 0.05)$.

\section{DISCUSSION}

The PGPR (Bacillus subtilis) inoculation and co-inoculation with AMF caused an increase in seedlings survival. In this period, the survival of seedling is directly related with the increase in cuttings rooting. $B$ subtilis can assist in this process through the phytohormone production of indoleacetic acid (IAA) (Radhakrishnan et al., 2017). According to Teixeira et al. (2007), the mini cuttings of eucalypt clones in substrate with inoculation of $B$ subtilis shows better root formation, and this result allows optimization of seedling development in clonal nurseries. The presence of rhizobacteria $B$. subtilis can directly influence plant growth not only by phytohormone production
(Ali et al., 2009; Galaviz et al., 2018) but also by stressinhibiting enzymes, siderophores, and indirect P-solubilization (Meng et al., 2016).

Root colonization by AMF Rhizophagus clarus was around $60 \%$ at 90 days after planting. The AMF efficiency must be evaluated with data of vegetative development, since symbiosis may not be effective, with high colonization rates, depending on the host. Arbuscular mycorrhizal (AM) association can be influenced and differentiated by vegetal species, clones, and cultivars, as well as by inoculated AMF species (Smith and Smith, 2011). In an evaluation of Indian native AMF species (Funneliformis mosseae, Glomus intraradices, and Glomus proliferum), Ajeesh et al. (2017) observed that colonization 
TABLE 7 | Tree volume, mean annual increment, and current annual increment at 3 years old in plants of Tectona grandis in Mato Grosso state, Brazil.

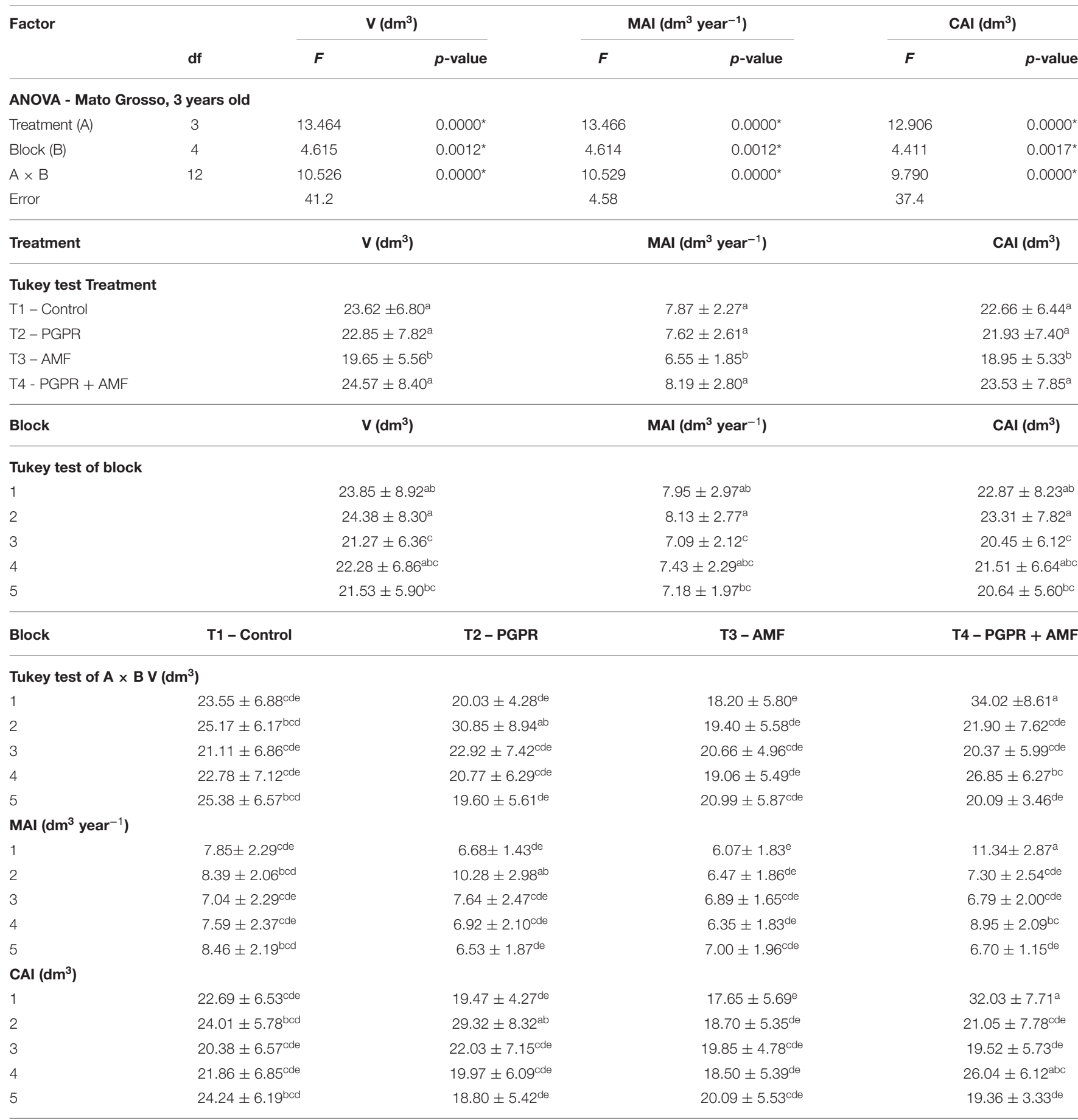

*Significant difference $(p \leq 0.05)$. Same letter does not differ by the Tukey test $(p \leq 0.05)$.

range was from 15 to $36 \%$, and that teak response was better with $G$ proliferum than with other mycorrhizal species. In Indonesia, a study on Acaulospora sp., Gigaspora sp., and mixed Acaulospora sp. and Gigaspora sp, combined with different doses of compost in soil, showed that seedlings inoculated with Gigaspora sp. and 15\% of compost increased seedling quality, and the root colonization of teak in this study ranged from 0 to $36 \%$ for Acaulospora sp and from 32 to $74 \%$ for Gigaspora sp (Prayudyaningsih and Sari, 2016).

AMF colonization response also can be modulated by the successional status of plant host. Tectona grandis has been reported as an early successional species (Chen et al., 2011). Early successional woody species with high metabolic rate dominate the initial stages of succession, occur in highly illuminated 
TABLE 8 | Tree volume and mean annual increment at 2 years old in plants of Tectona grandis in Pará state, Brazil.

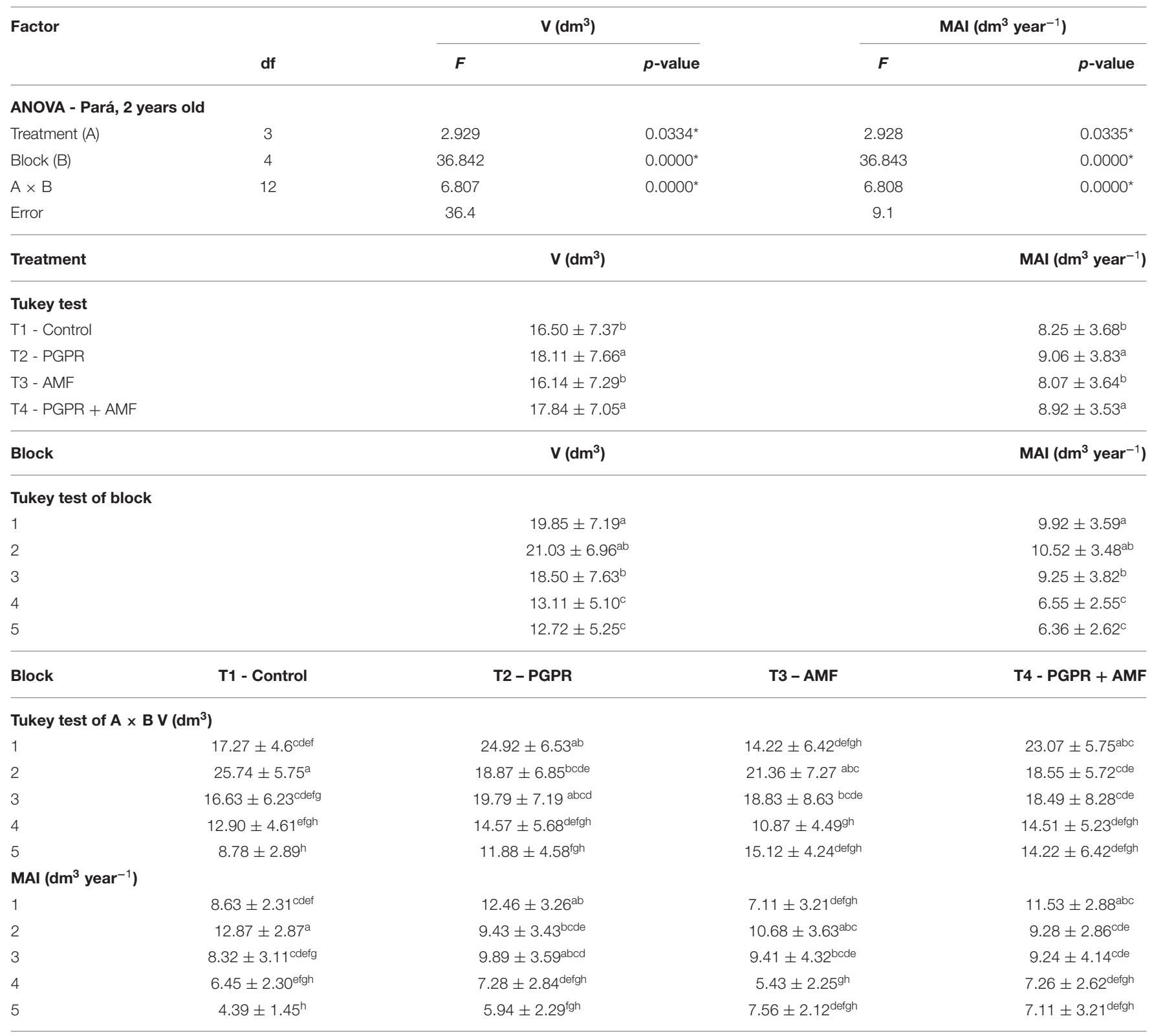

${ }^{*}$ Significant difference $(p \leq 0.05)$. Same letter does not differ by the Tukey test $(p \leq 0.05)$.

environments, and usually exhibit high mycorrhizal colonization and responsiveness. In contrast, late-successional woody species with low metabolic rate dominant in mature forest occur in an environment with low light incidence and exhibit low mycorrhizal colonization and responsiveness (Zangaro et al., 2007). High mycorrhizal colonization and responsiveness or early successional species can be modified when these are propagated in fertile substrates, leading to modification of the root architecture by the increase in root density and specific root length.

Biometric evaluation in clonal seedlings showed that $R$ clarus colonization induced a differential response in growth parameters. $R$ clarus had no negative effect on the growth of aerial parts of teak. It also did not significantly affect biomass and branching of the root system. Stem diameter was decreased, and root branching stimulated the co-inoculated PGPR + AMF treatment (Figure 3). One of the factors that lead to this response can be the substrate fertility and container volume used in nurseries. Some authors, such as Zangaro et al. (2015), have described a similar response in seedlings inoculated with AMF in $50 \mathrm{~cm}^{3}$ tubes and high fertility substrates, where plants showed growth depression. The depression was possibly related to the AMF association cost for the host plant, especially related to carbon; AMF are dependent on organic carbon from plant photosynthates, and the benefits of plant-fungus association can be affected by the decrease in the photosynthetic rate of 
TABLE 9 | Tree volume, mean annual increment, and current annual increment at 3 years old in plants of Tectona grandis in Pará state, Brazil.

\begin{tabular}{|c|c|c|c|c|c|c|c|}
\hline Factor & df & \multicolumn{2}{|c|}{$V\left(d^{3}\right)$} & \multicolumn{2}{|c|}{ MAI $\left(\mathrm{dm}^{3}\right.$ year-1 $\left.^{-1}\right)$} & \multicolumn{2}{|r|}{ CAI $\left(\mathrm{dm}^{3}\right)$} \\
\hline Treatment (A) & 3 & 5.237 & $0.0015^{\star}$ & 5.237 & $0.0015^{\star}$ & 5.299 & $0.0014^{*}$ \\
\hline Block (B) & 4 & 27.375 & $0.0000^{\star}$ & 27.378 & $0.0000^{*}$ & 20.983 & $0.0000^{*}$ \\
\hline$A \times B$ & 12 & 7.408 & $0.0000^{*}$ & 7.409 & $0.0000^{*}$ & 6.553 & $0.0000^{*}$ \\
\hline Treatment & & \multicolumn{2}{|c|}{$V\left(\mathrm{dm}^{3}\right)$} & \multicolumn{2}{|r|}{ MAI $\left(\mathrm{dm}^{3}\right.$ year $\left.^{-1}\right)$} & \multicolumn{2}{|r|}{$\mathrm{CAI}\left(\mathrm{dm}^{3}\right)$} \\
\hline \multicolumn{8}{|c|}{ Tukey test Treatment } \\
\hline T1 - Control & \multicolumn{3}{|c|}{$128.64 \pm 7.37^{\mathrm{b}}$} & \multicolumn{2}{|r|}{$42.88 \pm 3.68^{b}$} & \multicolumn{2}{|r|}{$112.14 \pm 32.33^{b}$} \\
\hline T2 - PGPR & \multicolumn{3}{|c|}{$144.61 \pm 7.66^{\mathrm{a}}(\uparrow 11.04 \%)$} & \multicolumn{2}{|r|}{$48.20 \pm 3.83^{a}$} & \multicolumn{2}{|r|}{$126.50 \pm 32.63^{a}$} \\
\hline \multicolumn{8}{|l|}{ Tukey test of block } \\
\hline 1 & & & $19^{a}$ & & $50.99 \pm 11.06^{\mathrm{a}}$ & & $133.13 \pm 29.78^{a}$ \\
\hline 2 & & & $.06^{\mathrm{a}}$ & & $48.85 \pm 12.02^{\mathrm{a}}$ & & $125.52 \pm 31.70^{\mathrm{a}}$ \\
\hline 3 & & & $.70^{\mathrm{a}}$ & & $47.89 \pm 12.23^{a}$ & & $125.18 \pm 31.45^{\mathrm{a}}$ \\
\hline 4 & & & $26^{b}$ & & $39.23 \pm 7.75^{b}$ & & $104.58 \pm 20.78^{b}$ \\
\hline 5 & & & $14^{\mathrm{b}}$ & & $39.40 \pm 11.05^{b}$ & & $105.47 \pm 29.22^{b}$ \\
\hline Block & T1 - Control & & T2 - PGPR & & T3 - AMF & & T4 - PGPR + AMF \\
\hline Tukey test of $A x$ & $\left(\mathrm{dm}^{3}\right)$ & & & & & & \\
\hline 2 & $55.16 \pm 11.38^{a}$ & & $47.69 \pm 12.31^{\text {abcde }}$ & & $51.66 \pm 11.16^{\mathrm{abc}}$ & & $41.16 \pm 8.94^{\text {def }}$ \\
\hline 3 & $43.12 \pm 9.16^{\text {cdef }}$ & & $50.90 \pm 13.14^{\mathrm{abcd}}$ & & $49.18 \pm 13.15^{\text {abcde }}$ & & $47.72 \pm 12.22^{\text {abcde }}$ \\
\hline 4 & $39.09 \pm 7.40^{\text {ef }}$ & & $43.20 \pm 8.46^{\text {cdef }}$ & & $36.39 \pm 6.56^{\mathrm{fg}}$ & & $39.34 \pm 7.94^{e f}$ \\
\hline 5 & $25.34 \pm 6.71^{g}$ & & $41.56 \pm 6.81^{\text {cdef }}$ & & $43.10 \pm 6.83^{\text {cdef }}$ & & $44.19 \pm 12.39^{\text {cdef }}$ \\
\hline $\mathrm{CAI}\left(\mathrm{dm}^{3}\right)$ & & & & & & & \\
\hline 1 & $127.22 \pm 17.71^{\mathrm{abcde}}$ & & $145.73 \pm 38.71^{\mathrm{a}}$ & & $118.88 \pm 25.01^{\text {abcdef }}$ & & $140.89 \pm 28.35^{\mathrm{ab}}$ \\
\hline 2 & $139.74 \pm 30.14^{\mathrm{abc}}$ & & $124.19 \pm 32.95^{\text {abcdef }}$ & & $133.61 \pm 28.87^{\mathrm{abc}}$ & & $104.93 \pm 24.63^{\mathrm{def}}$ \\
\hline 3 & $112.72 \pm 24.56^{\text {cdef }}$ & & $132.92 \pm 34.26^{\mathrm{abcd}}$ & & $128.71 \pm 33.35^{\text {abcde }}$ & & $124.68 \pm 30.60^{\text {abcdef }}$ \\
\hline 4 & $104.35 \pm 18.84^{e f}$ & & $115.02 \pm 25.78^{\text {abcdef }}$ & & $98.31 \pm 16.70^{f}$ & & $103.51 \pm 20.97^{e f}$ \\
\hline 5 & $67.23 \pm 18.76^{9}$ & & $112.80 \pm 17.22^{\text {cdef }}$ & & $114.18 \pm 17.75^{\text {bcdef }}$ & & $118.36 \pm 31.87^{\text {abcdef }}$ \\
\hline
\end{tabular}

${ }^{*}$ Significant difference $(p \leq 0.05)$. Same letter does not differ by the Tukey test $(p \leq 0.05)$.

$\uparrow$ Percentage of gain in relation to the control treatment.

environments with light limitation (Smith and Read, 2008). In this context, the carbon cost of AM overcomes the benefits of mineral absorption for the plant. Therefore, the allocation of resources for the maintenance of AMF can be advantageous for the plant, although it does not result in large accumulation of vegetative biomass, as the nutrients acquired via AMF can be allocated to increase the growth capacity of the plants in the field.

The nutrients in the foliar analysis for the nursery phase correlated positively with the treatments with microorganisms, in contrast to the control treatment, which did not present any correlation. The chemical properties of soils can be limiting for 
teak growth (Jerez-Rico and Coutinho, 2017). Well-nourished seedlings can be fundamental for good development in the field.

In addition to well-nourished seedlings in the field, the presence of PGPR and AMF can bring several benefits. For example, teak is demanding the availability of nutrients, such as nitrogen, phosphorus, potassium, calcium, and magnesium. Base saturation should be $>50 \%$, high $\mathrm{pH}(>5.5)$ and low aluminum presence (Matricardi, 1989; Jerez-Rico and Coutinho, 2017). The AMF have been reported to increase the tolerance of teak trees to acidity or high concentrations of Al (Alvarado et al., 2004), and PGPR can be acting in P-solubilization (Meng et al., 2016), helping the plants not to suffer in poor soils such as the soils in the planting areas of this experiment.

The beneficial approach of microorganism inoculation for the development of woody plants in fields has been reported (Siviero et al., 2008; Cely et al., 2016; Duin et al., 2019). Root colonization by AMF in teak ( $T$ grandis L.f.) has been evaluated by other authors, such as Irianto and Santoso (2005). In this study, the inoculation of Glomus aggregatum and a mixture containing Gigaspora margarita, Glomus manihotis, Glomus etunicatum, and Acaulospora spinosa accelerated the height and diameter growth by 61 and 47\%, respectively, after 3 months in the field. In our study, in the Pará state, plant growth was positively affected by PGPR in both second and third year and by PGPR + AMF in the third year with the increase in V by $11.04 \%$ (PGPR) followed by PGPR + AMF with an increase of $5.81 \%$ compared with the control (Tables 6, 7).

The potential of the inoculation of microorganisms for teak development in the nursery and field was recently shown by Raghu et al. (2020), showing that the inoculation of a microbial consortium (A leptoticha $+A$ chroococcum $+T$ harzianum) can improve the growth of plants $289 \%$ more than uninoculated plants. These responses of growth promotion can vary depending on the species of microorganisms inoculated, climate characteristics in the field, and genetic profile of teak cultivars, as observed in the evaluations at 2 and 3 years for tree volume (V), mean annual increment (MAI), and current annual increment (CAI).

Thus, a combination of bio-based products in the production of teak seedlings can provide quality seedlings that have good results in the field, even on nutritionally

\section{REFERENCES}

Ajeesh, R., Santhoshkuma, A.V., and Go, S. (2017). Screening of selected native arbuscular mycorrhizal fungi at different levels for their symbiotic efficiency with Tectona grandis seedlings. J. Trop. For. Sci. 29, 395-403. doi: 10.26525/jtfs2017.29.4. 395403

Akinrinlola, R. J., Yuen, G. Y., Drijber, R. A., and Adesemoye, A. O. (2018). Evaluation of Bacillus strains for plant growth promotion and predictability of efficacy by in vitro physiological traits. Int. J Microb. 2018:5686874. doi: $10.1155 / 2018 / 5686874$

Alam, M., Khaliq, A., Sattar, A., Shukla, R.S., Anwar, M., and Seema Dharni, S. (2011). Synergistic effect of arbuscular mycorrhizal fungi and Bacillus subtilis on the biomass and essential oil yield of rose-scented poor soils. The adoption of the use of commercial bio-based products helps to implement this technology in the routine of teak-producing nurseries.

\section{DATA AVAILABILITY STATEMENT}

The original contributions presented in the study are included in the article/supplementary materials, further inquiries can be directed to the corresponding author/s.

\section{AUTHOR CONTRIBUTIONS}

FS, LV, and IH: coordination, execution, monitoring of experiments, and data processing. $\mathrm{DS}, \mathrm{AP}, \mathrm{MB}, \mathrm{BF}, \mathrm{DD}, \mathrm{AC}$, and AS: laboratory and field data collection. BG, ML, and GA: arbuscular mycorrhizal inoculum production, scientific support, and manuscript writing. RF and MT: idealization, coordination, and project planning. ES, JB, and FT: coordination, technical, and financial support at the Teak Resources Company (TRC). All authors contributed to the article and approved the submitted version.

\section{FUNDING}

The authors acknowledge the Conselho Nacional de Desenvolvimento Científico e Tecnológico (CNPq) and Coordenação de Aperfeiçoamento de Pessoal de Nível Superior (CAPES) for making this study possible via the PIBIC (Institutional Scientific Initiation Scholarship Program) and by providing funds for M.Sc. degrees, the Teak Resources Company (TRC) for economic, technical, and logistic support to the conduct experiments in the nursery and field, and to the Universidade Federal de Mato Grosso/Research Dean PROPeq/PROPG-UFMT, Laboratório de Patologia Florestal of Universidade Federal de Viçosa and the Teak Resources Company (TRC) for economic support for publishing fees. The authors declare the Teak Resources Company (TRC) was not involved in the study design, collection, analysis, interpretation of data, the writing of this article or the decision to submit it for publication. geranium (Pelargonium graveolens). Arch. Agron. Soil. Sci. 57, 889-898. doi: 10.1080/03650340.2010.498013

Ali, B., Sabri, A. N., Ljung, K., and Hasnain, S. (2009). Auxin production by plant associated bacteria: impact on endogenous IAA content and growth of Triticum aestivum L. Lett. Appl. Microbiol. 48, 542-547. doi: 10.1111/j.1472-765X.2009.02565.X

Alvarado, A., Chavarría, M., Guerrero, R., Boniche, J., and Navarro, J. R. (2004). Características edáficas y presencia de micorrizas en plantaciones de teca (Tectona grandisL.f.) en Costa Rica. AgronomíaCostarricense. 28, 89-100. Available online at: https://www.redalyc.org/articulo.oa?id=43628109

Andrade, G., and Cely, M.V.T. (2019). Processo de Produção e Inoculação de Fungos Micorrízicos Arbusculares. BR Patent No 102019008109-0 A2.

Awasthi, A., Bharti, N., Nair, P., Singh, R., Shukla, A., Gupta, M., et al. (2011). Synergistic effect of Glomus mosseae and nitrogen fixing Bacillus subtilis strain 
Daz26 on artemisin content in Artemisia annua L. Appl. Soil Ecol. 49, 125-130. doi: 10.1016/j.apsoil.2011.06.005

Carneiro, M. F., Albuquerque, W. W., Souza, C. O., Câmara, A. P., Silva, J. G. M., and Galvão, E. K. S. (2018). Radial growth and artificial form factor of teak trees in Alta Floresta do Oeste, Rondônia. Rev. Cienc. Agrar. 61, 1-7. doi: 10.22491/rca.2018.2702

Cely, M. V. T., Siviero, M. A., Emiliano, J., Spago, F.R., Freitas, V. F., Barazetti, A. R., et al. (2016). Inoculation of Schizolobiumparahyba with mycorrhizal fungi and plant growth-promoting rhizobacteria increases wood yield under field conditions. Front. Plant Sci. 7, 1-13. doi: 10.3389/fpls.2016.01708

Chen, J.W, Zhanga, Q., Lia, X.S., and Cao, K.F. (2011). Steady and dynamic photosynthetic responses of seedlings from contrasting successional groups under low-light growth conditions. Physiol. Plantarum. 141, 84-95. doi: 10.1111/j.1399-3054.2010.01414.x

Duin, V. F. F., Liuti, G., Prado, N. V., Cely, M. V. T., Andreata, M. F. L., Santos, I. M. O., et al. (2019). Effect of the fertilization and growth promoting microrganisms on Schizolobiumparahyba. Semina Ciênc. Agrár. 40, 1747-1760. doi: 10.5433/1679-0359.2019v40n5p1747

FAO (1994). Soil Map of the World. Revised Legend With Corrections. Rome: FAO-UNESCOISRIC, 140.

Galaviz, C., Lopez, B. R., Bashan, L. E., Hirsch, A. M., Maymon, M., and Bashan, Y. (2018). Root growth improvement of mesquite seedlings and bacterial rhizosphere and soil community changes are induced by inoculation with plant growth-promoting bacteria and promote restoration of eroded desert soil. Land Degrad. Dev. 2018:2904. doi: 10.1002/ldr.2904

Giovannetti, M., and Mosse, B. (1980). An evaluation of techniques for measuring vesicular arbuscular mycorrhizal infection in roots. New Phytol. 84, 489-500. doi: 10.1111/j.1469-8137.1980.tb04556.x

Hashem, A., Abd_Allah, E. F., Alqarawi, A. A., Al-Huqail, A. A., and Shah, M. A. (2016). Induction of osmoregulation and modulation of salt stress in Acacia gerrardii Benth. by arbuscular mycorrhizal fungi and Bacillus subtilis (BERA 71). Bio. Med. Res. Int. 2016:6294098. doi: 10.1155/2016/6294098

IBÁ. (2019). Relatório IBÁ 2019 - Desempenho do setor florestal em 2018. Brasília.

Irianto, R.S.B., and Santoso, E. (2005). Effect of arbuscular mycorrhiza fungi inoculation on teak (Tectona grandis Linn. F) at cikampek, west Java. J. For. Res. 2, 69-73. doi: 10.20886/ijfr.2005.2.2.69-73

Jerez-Rico, M., and Coutinho, S. A. (2017). "Establishment and management of planted teak forests," in The Global Teak Study. Analysis, Evaluation and Future Potential of Teak Resources IUFRO World Series, Vol. 36, eds W. Kollert, and M. Kleine (Vienna), 49-65.

Köppen, W. (1936). "Das geographische System der Klimate," in Handbuch der Klimatologie, Vol. 1, eds W. Köppen, and R. Geiger (Berlin: Verlag von Gebrüder Borntraeger), 1-44.

Marulanda-Aguirre, A., Azcón, R., Ruiz-Lozano, J. M., and Aroca, R. (2007). Differential effects of a Bacillusmegaterium Strain on Lactuca sativa plant growth depending on the rigin of the arbuscular mycorrhizal fungus coinoculated: physiologic and biochemical traits. J. Plant. Growth Regul. 27, 10-18. doi: 10.1007/s00344-007-9024-5

Matricardi, W. A. T. (1989). Efeitos dos fatores do solo sobre o desenvolvimento da teca (Tectona grandis L. F.) cultivada na grande Cáceres - Mato Grosso (Dissertação, Mestrado em Ciências Florestais), Universidade de São Paulo, Piracicaba, 135.

Medina, A., Probanza, A., Gutierrez Mañero, F. J., and Azcón, R. (2003). Interactions of arbuscular-mycorrhizal fungi and Bacillus strains and their effects on plant growth, microbial rhizosphere activity (thymidine and leucine incorporation) and fungal biomass (ergosterol and chitin). App. Soil. Ecol. 22, 15-28. doi: 10.1016/S0929-1393(02)00112-9

Meng, Q., Jiang, H., and Hao, J. J. (2016). Effects of Bacillus velezensis strain BAC03 in promoting plant growth. Biol. Control. 98, 18-26. doi: 10.1016/j.biocontrol.2016.03.010

Meza, A., Rodriguez, J., Gatti, K., and Espinoza, E. (2015). Propagación de arboles de teca Tectona grandis L. f. por miniestacas. Temas Agrar. 20, 43-48. doi: $10.21897 /$ rta.v20i2.757

Pandey, D., and Brown, C. (2000). Teak: A Global Overview (Unasylva: FAO), 3-13.

Phillips, J. M., and Hayman, D. S. (1970). Improved procedures for clearing roots and staining parasitic and vesicular-arbuscular mycorrhizal for rapid assessment of infection. Trans. Br. Mycol. Soc. 55, 158-161. doi: 10.1016/S0007-1536(70)80110-3
Prayudyaningsih, R., and Sari, R. (2016). The application of arbuscular mycorrhizal fungi (AMF) and compost to Improve the growth of Teak seedlings (Tectona grandis Linn. f.) on limestone post-mining soil. J. P. K. Wallacea 5, 37-46. doi: 10.18330/jwallacea.2016.vol5iss1pp37-46

R Core Team (2020). R: A Language and Environment for Statistical Computing. Vienna: R Foundation for Statistical Computing. Available online at: https:// www.R-project.org/ (accessed December 3, 2020).

Radhakrishnan, R., Hashem, A., and Abd_Allah, E. F. (2017). Bacillus: a biological tool for crop improvement through bio-molecular changes in adverse environments. Front. Physiol. 8, 1-14. doi: 10.3389/fphys.2017. 00667

Raghu, H. B., Ashwin, R., Ravi, J. E., and Bagyaraj, D. J. (2020). Microbial consortium improved growth and performance of Teak (Tectona grandis L.f.) in nursery and field trials. Proc. Natl. Acad. Sci. India Sect. B Biol. Sci. 90, 903-909. doi: 10.1007/s40011-019-01163-0

Rillig, M.C., and Mummey, D.L. (2006). Mycorrhizas and soil structure. New Phytol. 171, 41-53. doi: 10.1111/j.1469-8137.2006.01750.x

Rodrigues, L.A., Barroso, D.G., and Figueredo, F.A.M. (2018). Fungos micorrízicos arbusculares no crescimento e na nutrição mineral de mudas de Tectona grandis L. F. Ciência Florest. 28, 25-34. doi: 10.5902/1980509831572

Ryser, P., and Lambers, H. (1995). Root and leaf attributes accounting for the performance of fast- and slow-growing grasses at different nutrient supply. Plant Soil. 170, 251-265. doi: 10.1007/BF00010478

Schuhli, G.S., and Paludzyszyn Filho, E. (2010). O cenário nacional da silvicultura de teca (Tectona grandis L. f.) e perspectivas de melhoramento. Pesqui. Florest. Bras. 30, 217-230. doi: 10.4336/2010.pfb.30.63.217

Siviero, M. A., Marega, A., Lima Dos Santos, D., Rosselli, B. R., Huh, Y. S., Santinoni, I., et al. (2008). Interaction among N-fixing bacteria and AM fungi in Amazonian legume tree (Schizolobiumamazonicum) in field conditions. Appl. Soil Ecol. 39, 144-152. doi: 10.1016/j.apsoil.2007.12.004

Smith, S. E., and Read, D. J. (2008). "Growth and carbon economy of arbuscular mycorrhizal symbionts," in Mycorrhizal Symbiosis, 3rd $E d n$, eds S. E. Smith, and D. J. Read (London: Elseiver), 119-187. doi: 10.1016/B978-012370526-6.50006-4

Smith, S. E., and Smith, F. A. (2011). Roles of arbuscular mycorrhizas in plant nutrition and growth: new paradigms from cellular to ecosystem scales. Ann. Rev. Plant Biol. 62, 227-250. doi: 10.1146/annurev-arplant-042110103846

Teixeira, D. A., Alfenas, A. C., Mafia, R. G., Ferreira, E. M., Siqueira, L., Maffia, L. A., et al. (2007). Rhizobacterial promotion of eucalypt rooting and growth. Brazil. J. Microbiol. 38, 118-123. doi: 10.1590/\$1517-838220070001 00025

Zangaro, W., Nishidate, F.R., Vandresen, J., Andrade, G., and Nogueira, M.A. (2007). Root mycorrhizal colonization and plant responsiveness are related to root plasticity, soil fertility and successional status of native woody species in southern Brazil. J. Trop. Ecol. 23, 53-62. doi: 10.1017/S02664674060 03713

Zangaro, W., Torezan, M. D., Rostirola, L. V., Souza, P. B., and Nogueira, M. A. (2015). Influence of mycorrhizas, organic substrates and container volumes on the growth of Heliocarpuspopayanensis Kunth. Cerne 21, 395-403. doi: 10.1590/01047760201521031335

Conflict of Interest: JB, ES, and FT are employed by the Teak Resources Company (TRC).

The remaining authors declare that the research was conducted in the absence of any commercial or financial relationships that could be construed as a potential conflict of interest.

Copyright (C) 2021 Alexandre, Della Flora, Henrique, da Silva, Mercedes, Cardoso Silva, Silva de Oliveira, Bondespacho da Silva, Formelh Ronning, Dreher, Gionco Cano, Andreata, Barbosa Filho, Santos, Takisawa, Alfenas, Andrade and Cely. This is an open-access article distributed under the terms of the Creative Commons Attribution License (CC BY). The use, distribution or reproduction in other forums is permitted, provided the original author(s) and the copyright owner(s) are credited and that the original publication in this journal is cited, in accordance with accepted academic practice. No use, distribution or reproduction is permitted which does not comply with these terms. 